\title{
Brand Fidelity: A Relationship Maintenance Perspective
}

\begin{abstract}
An in-depth literature review associated with consumer/brand research provides the foundation for this paper through explicating the evolution of this important research stream. The literature findings highlight significant challenges in the conceptualisation and measurement of key consumer-related constructs such as brand loyalty, brand commitment and brand love. Drawing upon these findings, the authors propose that relationship maintenance mechanisms (i.e. cognitive and behavioural) provide the key to measurement and prediction of consumer/brand relationship strength. On this basis, this paper offers brand fidelity as a novel approach in understanding how consumers demonstrate their love and commitment for the brand through engaging, subconsciously or otherwise, in relationship maintenance cognitions and behaviours. Defined as the consumer's faithfulness to a brand partner demonstrated by an aggregate of behaviours (i.e. accommodation/forgiveness, willingness to sacrifice) and cognitions (i.e. derogation of alternatives, cognitive interdependence and positive illusions) that maintain relationship stability and durability, brand fidelity provides a solid foundation for future research offering significant value to academics and brand practitioners alike.
\end{abstract}

\section{Key Words:}

Consumer/Brand Relationships, Brand Commitment, Brand Loyalty, Relationship Maintenance, Relationship Fidelity 


\section{INTRODUCTION}

For decades academics and practitioners have directed considerable effort toward understanding and measuring consumer responses to product/brand offerings. Early consumer research was centred around the notion of customer satisfaction (e.g., Anderson, 1973; Pfaff, 1972), with a heavy focus on customer expectations and perceived product performance prevailing (e.g., Day, 1977; Miller, 1977). The 80s and 90s brought about a changing research focus to brands (as opposed to products) and the need for understanding the longer-term outcomes of customer satisfaction. Consequently, many studies were focused on defining and measuring such constructs as brand loyalty and brand commitment (e.g., Amine, 1998; Jacoby and Chestnut, 1978). The current era of consumer research has embraced psychological theory relating to interpersonal relationships, with the notion of brand love dominating much of the current consumer literature (e.g., Albert et al., 2008; Carroll and Ahuvia, 2006; Fetscherin et al., 2014; Langner et al., 2014; Long-Tolbert and Gammoh, 2012; Rauschnabel and Ahuvia, 2014).

In order to further progress this research stream, where consumers seek out complex need fulfilment through active participation in the co-creation and maintenance of brands, it is critical we learn from past research trajectories. Thus, the goal of this paper is twofold. First, the relevant literatures surrounding consumers and brands are reviewed in order to make sense of our knowledge from a historical, or evolutionary, perspective. Such an in-depth review helps us understand how our knowledge of consumer/brand relationships has evolved over time and highlights the criticisms and challenges that have moved academic and practitioner thought through the various research stages. 
Second, in identifying historical trends in the literature, this paper suggests future consideration of adopting a research mind-set beyond understanding how and why consumer/brand relationships develop, to a focus on how such relationships are maintained. In this respect, we make justification for proposing a new construct, brand fidelity, that is centered on consumer actions and thoughts, which exemplify active participation in the maintenance of strong consumer/brand relationships. Defined as the consumer's faithfulness to a brand partner manifested through various behaviours (i.e. accommodation/forgiveness performance and price) and cognitions (i.e. derogation of alternatives and cognitive interdependence) that maintain relationship stability and durability, brand fidelity provides opportunity to significantly enhance how we view and, subsequently, measure consumer/brand relationships in the future. We offer brand fidelity as a construct that augments our understanding of consumer/brand relationships and, in doing so, provides a comprehensive framework for future research to explore its operationalization and, subsequent, diagnostic capabilities through empirical validation. As such, this paper has solid implications for both brand researchers and brand practitioners.

\section{METHODOLOGY}

The literature review of this study is based on the logic of purposeful sampling, whereby qualitative data (in this case, publications), which illuminates issues relating to the research purpose (Patton, 2002), is gathered and analysed through a three-step process. Following a similar methodology to that used by Green et al. (2016), the first step, known as orientation, involves conducting a broad review of the literature to provide initial summaries of research 
problems, theories, relative emphasis and trends relating to consumer responses to brands. Building on the findings of step one, the second step, orientation, involves further search for additional literature to highlight patterns and/or deviations in philosophical outlooks and assumptions associated with the conceptualisation and measurement of consumer/brand relationships. Finally, in step three (i.e. delineation) the findings of step two are used to identify evolutionary shifts in the trajectory of consumer/brand research. As a result, the findings enable the ensuing discussion relating to the evolution of consumer/brand relationship research and which is graphically depicted in Figure 1.

\section{EVOLUTION OF CONSUMER/BRAND RELATIONSHIPS}

In the 1970s, marketing theory and practice was centrally focused on the concept of customer satisfaction (e.g., Anderson, 1973; Day, 1977; Miller, 1977; Pfaff, 1972). This was an era when marketplace offerings were largely firm-controlled and the satisfaction of customers' needs and wants was considered paramount to firm profitability (Churchill and Surprenant, 1982). Thus, the bulk of early research was concentrated on the nature of customer satisfaction and its antecedents (e.g., Oliver, 1977; Olshavsky and Miller, 1972; Olson and Dover, 1976). As a result, the measurement of customer expectation (dis)confirmation and perceived performance associated with products dominated marketing research foci during this period (e.g., Day 1977; Miller 1977).

Building on early customer satisfaction research, the 1980s and 90s brought about research momentum in two keys areas (1) customer satisfaction outcomes, and (2) the focus being on brands, rather than products (Reynolds and Gutman, 1984; Sheth and Parvatiyar, 1995). 
While the notion of customer satisfaction "has long been considered one of the cornerstones of marketing strategy" (Roy et al., 2013, p. 329), the use of satisfaction as a proxy for loyalty was considered to be fundamentally flawed (Oliver, 1999) as not all satisfied customers are loyal and, while loyal customers are typically satisfied, satisfaction cannot be assumed due to the potential effect of habitual supply conditions (Amine, 1998). On this basis, there was a significant shift of research concentration centred on the consequences, or outcomes, of satisfaction (e.g., Oliver, 1999; Russell-Bennett et al., 2007).

In addition, the interest in the brand concept was sparked by the recognition that consumers have different types of needs over and above that relating to the product's functional (or performance) capabilities (Keller, 1993). As such, the brand management concept (Park et al., 1986) encapsulated more than mere product performance and positioning, but rather the introduction, elaboration and fortification of brand meaning in consideration of consumers' functional, symbolic (e.g., Sirgy, 1982; Solomon, 1983) and experiential (e.g., Hirschman and Holbrook, 1992; McAlister, 1982) needs. In this sense, the brand focus represents a longterm orientation (Park et al., 1986) and the interest in consumer/brand relationships (Fournier, 1998) was sparked. In behavioural terms, the strength of consumer/brand relationships fundamentally stems from repeat purchase/patronage. However, relationships between consumers and brands are much more complex than that (Christodoulides and De Chernatony, 2010). As a result, there has been considerable research attention given to examining the aspects of such relationships, which has given rise to a plethora of literature focussed on brand loyalty, brand commitment (e.g., Crosby and Taylor, 1983; Mattila, 2001; Moorman et al., 1992) and, more recently, brand love (e.g., Albert and Merunka, 2013; Batra 
et al., 2012; Carroll and Ahuvia, 2006; Roy et al., 2013). As such, these constructs provide the basis for the ensuing discussions.

\section{Brand Loyalty:}

The nature and measurement of brand loyalty has long been debated. At the fundamental level, conceptualizations of the construct were drawn from the behavioural characteristics of "loyal customers", operationalised as repeat purchase behaviour, purchase and switching intentions (Jacoby and Chestnut, 1978; Reichheld and Teal, 1996; Popp and Woratschek, 2017). However, others (Dick and Basu, 1994; Mattila, 2001; Mitra and Lynch, 1995; Leckie et al., 2016) have argued that loyalty also encompasses cognitive aspects evident in the decision-making process involving brand evaluation, preference and attitudes. On this basis, a widely accepted definition of brand loyalty is "the biased (i.e., non-random) behavioural response (i.e. purchase), expressed over time by some decision-making unit with respect to one or more alternative brands out of a set of such brands as is a function of psychological (decision-making) evaluative processes" (Jacoby and Chestnut, 1978, pp. 80-81). However, Fournier and Yao (1997) argue that, while this definition does capture the temporal nature of loyalty, it still fails to capture "the dynamic, evolutionary character of the phenomenon itself" (p. 453). On this basis, they proposed that brand loyalty is better understood from a relational perspective that specifically considers "the nuances of meaning, context and temporality" (Fournier and Yao, 1997, p. 454) in consumer/brand partnerships. Using idiographic analysis, Fournier (1998) proposes a model of brand relationship quality and stability/durability (p. 366) that identifies love/passion, self-connection, commitment, interdependence, intimacy and brand partner quality as being indicative of brand relationship 
quality. In this sense, Fournier (1998) argues that brand relationship quality provides a much richer understanding of the strength and sustainability of consumer/brand relationships that brand loyalty does not capture. While Fourier's (1998) BRQ model has since been criticised on the basis that not all brands relate to their customers in the same manner (Dowling, 2002), the value of the $B R Q$ model is drawn from the very comprehensive nature of the model and, as a result, it has been widely accepted, used and adapted.

\section{Brand Commitment:}

Often referred to interchangeably, brand commitment and brand loyalty have been the focus of much research since the 1970s. Brand commitment is proffered to represent the underlying motivations associated with repeat purchase behaviour and brand preference (i.e. brand loyalty) (Moorman et al., 1992). Specifically, it is argued that brand commitment provides more depth in our understanding of "loyal customers" as it captures the emotional aspects of consumer/brand partnerships (Mattila, 2006) that are highly indicative of relational strength (Moorman et al., 1992). In addition, as brand commitment essentially differentiates highly probable repeat purchase behaviour (i.e. true brand loyalty) and less probable repeat purchase behaviour (i.e. spurious brand loyalty), then commitment is considered a better indicator of brand loyalty depth (Jacoby and Kyner, 1973).

There are two types of commitment i.e. affective and calculative (Mattila, 2006; Cifci and Erdogan, 2016). Affective commitment is largely exemplified through the emotional bonds consumers have with brands. In other words, affective commitment represents the consumer's liking or attachment to the brand, over and above brand attribute evaluation 
(Morgan and Hunt, 1994). On the other hand, calculative commitment represents a cognitive evaluation of the benefits and costs attached to the brand (Hennig-Thurau and Klee, 1997; Jones et al., 2010). Thus, a consumer will remain committed to a brand if the perceived benefits of the brand continue to outweigh the perceived costs. This represents much more of a "head" purchasing strategy than "heart" purchasing strategy (i.e. affective commitment). However, affective commitment is more likely to produce long-term consistent behaviour, as opposed to calculative commitment, as it depends less on contingent factors associated with the brand (Amine, 1998; Punniyamoorthy and Raj, 2007). This exemplifies the significant role that emotion (or affect) plays in consumer/brand relationships (Fournier and Yao, 1997).

While there have been several attempts to define the underlying dimensions of the relatively complex and highly-related constructs of brand loyalty and commitment (Huang et al., 2007), the measurement of both has remained simplistically unidimensional. The majority of research, particularly focussed on the examination of antecedents to commitment/loyalty, has fundamentally used scales comprised of 2 to 6 items, with single items covering such aspects as general commitment/loyalty, switching behaviour, purchase intentions, price sensitivity and word-of-mouth (e.g., Chaudhuri and Holbrook, 2002; Eisingerich and Rubera, 2010; Kim et al., 2008; Nam et al., 2011, Pulligadda et al., 2016 and more). While such measurements capture an abridged evaluation of commitment/loyalty, they do little to pinpoint specific behaviours within consumer/brand relationships that are indicative of the depth on consumer/brand relationships. In fact, Fournier and Yao (1997) criticise the operationalization of the loyalty construct for being uninspired, non-diagnostic and conflicting. 


\section{Brand Love:}

Over the past decade, research related to brand love has gained momentum with considerable divergence in relation to the definitional boundaries of the brand love construct. Drawing on Sternberg's (1986) triangulation theory of love (i.e. intimacy, passion and decision/commitment), Shimp and Madden (1988) proposed that love (in consumption situations) comprises of liking, yearning and decision/commitment. This notion laid the groundwork for others (e.g., Ahuvia, 2005; Thomson et al., 2005; Wang and Wallendorf, 2004, and more) to empirically establish that love is, indeed, a valid consumption-related construct. However, research relating to the dimensions of brand love is voluminous and varied. For example, intimacy, passion, decision/commitment, strong positive feelings (affect), idealisation, memories, unicity, long term duration, anticipated separation distress, self-brand integration, dreams, uniqueness, beauty, declaration of affect, past behaviour, willingness to invest, friendship (extension of this relationship), and attitudes (e.g., Albert and Merunka, 2013; Albert et al., 2008; Batra et al., 2012; Carroll and Ahuvia, 2006; Fetscherin et al., 2014; Langner et al., 2014; Long-Tolbert and Gammoh, 2012; Maxian et al., 2013; Rauschnabel and Ahuvia, 2014; Rossiter, 2012; Roy et al., 2013; Sarkar et al., 2012), are all proposed dimensions that define brand love and many of these underpin the operationalization of brand love in empirical studies.

In addition, the lines between brand love dimensions, the antecedents to brand love and the outcomes of brand love are also considerably blurred. For example, self-brand integration and strong positive feelings (affect), identified by some (e.g., Batra et al., 2012; Langner et al., 2014; Maxian et al., 2013; Rauschnabel and Ahuvia, 2014, and more) as being dimensions of 
brand love, are proposed by others (e.g., Albert and Merunka, 2013; Carroll and Ahuvia, 2006; Sarkar et al., 2012; Wallace et al., 2014, and more) as being antecedents to brand love. While other antecedents are proposed to be product hedonism (Carroll and Ahuvia, 2006), romanticism (Sarkar et al., 2012), materialism (Roy et al., 2013), trust (Albert and Merunka, 2013), brand experience (de Oliveira Santini et al., 2018) partner quality and social support (Long-Tolbert and Gammoh, 2012).

To a lesser extent, confusion exists in relation to the outcomes of brand love, with trust being cited as a dimension of brand love (Albert et al., 2008), an antecedent of brand love (Albert and Merunka, 2013) and an outcome of brand love (Loureiro et al., 2012). Nevertheless, there appears to be some consensus over other brand love outcomes with purchase intention (Fetscherin et al., 2014; Sarkar et al., 2012), word-of-mouth recommendation/advocacy (Fetscherin et al., 2014; Sarkar et al., 2012), loyalty (Carroll and Ahuvia, 2006; Loureiro et al., 2012; Roy et al., 2013; Alnawas and Altarifi, 2016) and commitment (Albert and Merunka, 2013; Loureiro et al., 2012; Garg et al., 2016) being cited as prominent outcomes. However, given the disparate operationalization of these outcome constructs across studies, it is suggested that consensus may be an apparition based on construct labelling, rather than construct measurement/validity.

Given the conceptual disparities associated with the brand love construct, it is not surprising that its measurement is also highly debated. For example, Rossiter (2012) criticizes the conceptualizations and measurement of brand love by Batra et al. (2012) and others (e.g., Carroll and Ahuvia, 2006) on the basis that (1) the measures lack content validity, (2) the measurement scales should not be continuous because such measurement fails to 
distinguish between brand love and brand like, and (3) the measurement model (i.e., of Batra et al., 2012) should be formative rather than reflective. On this basis, Rossiter (2012) proposes an alternative contrastive single-item measure, including five response options ${ }^{1}$ and concludes that (1) brand love is an emotional state experienced by a minority of customers, (2) the proportion of "brand lovers" is dependent on product category, and (3) brand love (if achieved) equates to high behavioural returns.

In contrast, Zarantonello et al. (2016), promote the measurement of brand love via a 13-item scale covering five dimensions (i.e. fantasies and thoughts, attachment, self-expression, pleasure and idealisation). Furthermore, Bagozzi et al. (2017), consider brand love to be a highly complex multi-faceted construct in their development of a 26 -item scale covering 13 dimensions of brand love, including higher-order factors (i.e. self-brand integration, passiondriven behaviours, positive emotion connection) and other factors such as attitude strength and valence, long-term relationship and anticipated separation distress. As evidenced by the reviewed literature, it is apparent that academic consensus on the conceptualisation and measurement of brand love remains an elusive concept.

While there is conflicting views over the interpretation of brand love, there is growing agreement that love, when taken in the context of brands, is best understood from a relational rather than emotional perspective (Ahuvia et al., 2014). Yet several studies (e.g., Carroll and Ahuvia, 2006; Loureiro et al., 2012; Maxian et al., 2013) use unidimensional emotional measures in their operationalization of brand love. As love is both companionate

\footnotetext{
${ }^{1}$ Response options include hate, dislike, neutral, liking and love categories.
} 
(relating to the relationship) and passionate (relating to strong emotion), different types of love draw upon different aspects (Hatfield et al., 1984). However, as relationships develop and deepen, companionate love comes to the forefront as it represents the strengthening of and commitment to the relationship.

---- Insert Figure 1 Here.

\section{Summarizing the Consumer/Brand Relationship Evolution}

Through the literatures associated with customer satisfaction, brand loyalty, brand commitment and brand love, we have come a long way in understanding consumer/brand interactions and relationships. However, these literatures are still plagued with definitional inconsistencies relating to context (i.e. construct perspective), construct dimensionality (representation versus causation), construct positioning (i.e. antecedents versus outcomes) and, importantly, problems associated with gathering accurate perceptual interpretations from research subjects who are asked to self-report at a deep emotional level (Gupta and Zeithaml, 2006). These challenges are not identified to criticise the academic calibre of researchers or the academic rigour of previous work, but rather to highlight the need for new consumer/brand research to address these issues, where possible.

\section{WHERE TO FROM HERE?}

What we do know about strong brand emotions (i.e. commitment and love) is that they are best understood from a relational, rather than emotional perspective (Ahuvia et al., 2014). In 
fact, as early as 2001, Keller identified consumer/brand relationships to be characterized by intensity and activity. Intensity refers to the emotional attachment and/or sense of community the consumer derives from the brand relationship. Activity, on the other hand, refers to the behavioural manifestation of the emotional attachment (intensity) of brand loyalty. This is in line with Aaker's (1996) argument that consumers actively interact with brands, just as individuals do with their friends. Further to this, Keller (2009) later argues that brand resonance, which encapsulates another important aspect of contemporary consumer/brand relationships, is exemplified by the degree to which consumers are "in sync" with the brand.

These are all relevant points that are central to a more effective understanding and measurement of consumer/brand relationships. It is not our intention here to denounce the notion of brand commitment or brand love. To the contrary, we believe brand commitment and love are alive and well in today's brand-dominated marketplace. We suggest that, rather than trying to gauge the strength of emotions (i.e. intensity), a more palpable approach resides in recognising the behavioural (i.e. activity) and cognitive (i.e. "in sync") manifestations of those consumers who are committed and "in love" with a brand. We believe relationship maintenance provides us with the key in this respect.

Based on the notion that actions speak louder than words, we argue that relationship maintenance behaviour more accurately represents commitment strength over self-reported desires. Just as purchase intentions are not always found to be good indicators of purchase behaviour (Auger and Devinney, 2007; Carrington et al., 2010), we argue that, desires/emotions may not always be good indicators of relationship maintenance. From a 
measurement standpoint, just as personality inventories ask individuals to self-report their behaviours so that researchers can analyse personality type, we suggest researchers should ask individuals to self-report relationship maintenance behaviours in order to assess the degree of brand commitment/love they have toward the brand. Doing so circumvents the problems associated with respondent competency and data integrity (previously discussed) and brings us proximally closer to understanding brand performance. On this basis, we offer brand fidelity as a construct upon which to understand the cognitive and behavioural aspects of relationship maintenance, thus, providing future opportunity for effective brand performance measurement.

\section{BRAND FIDELITY: CONCEPTUAL DEVELOPMENT}

Challenging earlier social psychological approaches, which viewed relationship commitment as an outcome of positive affect, Rusbult (1980) first proposed the investment model, which was developed in the context of romantic relationships. In broad terms, the investment model of commitment processes depicts relationship commitment as directly affecting relationship behaviour and mediating the relationship between satisfaction, alternatives and investments on behaviour. Previous modelling of commitment largely relied on positive affect, such as satisfaction, to explain a person's commitment to a relationship. Rusbult (1980) went further to argue that commitment is also influenced by the existence (or not) of attractive alternatives (particularly relevant in the marketing context) and how much is already invested in the relationship. On this basis, Rusbult (1980) argued that the key to understanding commitment lies in determining why relationships persist, not just how satisfying they are. Rusbult et al. (1998) went on to explain that relationship commitment is 
a consequence of dependence and dependence represents the additive effect of satisfaction, investments and (lack of) alternatives. In this sense, relationship commitment is a psychological state that directly influences everyday behaviour in relationships and mediates the effects of satisfaction, alternatives and investments on behaviour (Rusbult et al., 2012).

The investment model has since been widely used in a number of relational contexts. For example, online travel behaviour (Nusair et al., 2010), B2B marketing (White and Yanamandram, 2007), financial marketing (Huang et al., 2007), mobile internet market (Giovanis, 2016) and brand loyalty (Li and Petrick, 2008) have all benefited by the application of the investment model in empirically advancing theory within these contextual domains. Nonetheless, all of these studies have centred their focus on the antecedents of commitment and little, if any, attention has been given to the relationship maintenance behaviours depicted as a consequence, or manifestation, of commitment or the desire to maintain relationships.

Importantly, in applying the growing momentum of the relationship metaphor to marketing contexts (e.g., Fournier and Yao, 1997; Morgan and Hunt, 1994), Fournier (1998) proposed the notion of "brand as relationship partner" and developed a comprehensive model of brand relationship quality and stability. Central to this model is the notion that brand relationships should be understood through "what consumers do with brands to add meaning to their lives" (p. 367). On this basis, Fournier (1998) argues that meaning, elaboration and reinforcement processes, associated with both relationship partners (i.e. consumer and brand), define the quality for the relationship. 
Since then, considerable research attention has been given to the brand relationship quality facets (i.e. love/passion, self-connection, intimacy, interdependence, brand partner quality and commitment) espoused in Fournier's (1998) model. For example, passion, selfconnection and intimacy commonly underpin contemporary research associated with brand love (e.g., Albert and Merunka, 2013; Batra et al., 2012). In addition, the underlying elements of brand relationship, such as brand trust, dependability and consistency (Fournier, 1998) have also taken up firm residence in the marketing literature (e.g., Albert and Merunka, 2013; Bengtsson et al., 2010; DelVecchio, 2000), along with a plethora of research relating to commitment and relationship interdependency (Bansal et al., 2004; Morgan and Hunt, 1994; Reynolds and Beatty, 1999). While the concepts contained within these literatures are often overlapping and contradictory (as previously discussed), they do confirm the validity of the relationship metaphor in consumer/brand research and play a key role in understanding how strong consumer/brand relationships are built.

However, of particular interest in this paper, is brand relationship maintenance (not development) and, thus, it is the factors, in Fournier's (1998) model, that provide the conduit between brand relationship quality and relationship stability/durability (i.e. accommodation, tolerance/forgiveness, biased partner perceptions, devaluation of alternatives and attribution biases) that attract our attention. Furthermore, the findings associated with Fournier's (1998) research are well aligned with the relationship maintenance mechanisms identified by Rusbult et al. (2001) and Rusbult et al. (2012) in their extension of Rusbult's (1980) investment model of commitment processes (i.e. accommodation, forgiveness, cognitive interdependence, derogation of alternatives, positive illusions and willingness to sacrifice). As such, the parallel between the two models (e.g., Fournier, 1998; Rusbult et al., 2012), and 
further calibrating research evidence, relating to individual relationship maintenance dimensions, establishes our understanding of relationship maintenance dimensions, and provide the definitional boundaries of our proposed construct i.e. brand fidelity.

\section{Relationship Maintenance Dimensions}

While the terms relationship stability, durability and fidelity have been referred to haphazardly in the literature (Brucks et al., 2000; Park et al., 2002; Ryan et al., 1999) few studies have attempted to offer a suite of behaviours/cognitions that define these terms. Notable exceptions are Fournier (1998), in the marketing context, and Rusbult et al., (2001) and Rusbult et al., (2012), in the context of romantic relationships. Contextual differences aside, the results of both studies share significant common ground, in that behavioural maintenance dimensions, such as accommodation/forgiveness and willingness to sacrifice, along with cognitive maintenance dimensions, such as cognitive interdependence, derogation of alternatives and positive illusions, appropriately frame what we currently know of relationship maintenance factors.

\section{Behavioural Dimensions:}

Accommodation and forgiveness are both explicated in the relevant relationship models of Fournier (1998), Rusbult et al. (2001) and Rusbult et al., (2012). The theory of accommodation was derived from the studies of Hirschman (1970), in relation to the decline of organisations, and Rusbult et al. (1982) who studied responses to dissatisfaction in close relationships. Accommodation refers to the situation where one party fails to follow through on a promise (or acts in some unexpected way) and the other party stifles the urge to 
retaliate (i.e. destructiveness); instead, responding in a manner that will promote the relationship (i.e. constructiveness) (Rusbult et al., 1991). From a consumer/brand perspective, the "accommodation" of the committed consumer to the brand, in times of below-par performance, not only shields the brand from financial loss (i.e. losing committed customers) but also helps diffuse the situation in the eyes of other consumers. In this sense, highly committed consumers behave in a manner that provides a safety net for the brand and protects/maintains the relationship (Fournier, 1998).

Forgiveness and accommodation share considerable common ground. Forgiveness, in ongoing relationships, refers to "the tendency to forgo vengeance and other destructive patterns of interaction, instead behaving towards the perpetrator in a positive and constructive manner" (Finkel et al., 2002, p. 958). In this sense, forgiveness underpins accommodation behaviour as forgiveness refers to an individual's stance (e.g. "I forgive you" /"I do not forgive you") enacted through behaviour, either destructive (i.e. retaliation) or constructive (i.e. relationship maintenance). In fact, measured from this perspective, Hegner et al. (2017) found that forgiveness was, indeed, a consequence of brand love.

There is a clearer distinction between the two in the context of romantic relationships as accommodation can mean simply agreeing with a partner in order to avoid an argument, whereas forgiveness may be related to much more serious matters that involve severe physical, psychological or social costs (Rusbult et al., 1991). In terms of brand relationships, the distinction is not quite so clear, with "bad behaviour" of the brand (in most cases) being performance or price related, causing a level of discomfort or inconvenience, rather than 
causing serious personal damage. It is on this basis that the lines between accommodation and forgiveness, in the context of consumer/brand relationships, become blurred.

Similarly, it is argued that willingness to sacrifice also has a close connection to accommodation and forgiveness (Rusbult et al., 2001). For example, from a consumer/brand perspective, when a negative brand experience occurs, the committed consumer's decision to forgive will motivate the enactment of constructive relationship behaviours (i.e.

accommodation) (Xie and Peng, 2009). However, in doing so, such behaviours may be costly, or stand in opposition to direct self-interest, thus, representing sacrifice.

Cleary explicated in Rusbult et al., (2012) model, as a key relationship maintenance factor, willingness to sacrifice, has received considerable attention in the marketing literature. Largely, research has studied sacrifice from the price (i.e. premiums) or product availability (i.e. stock shortages) point of view (Albert and Merunka, 2013; Carroll and Ahuvia, 2006; Jones et al., 2010; Jones and Taylor, 2007). However, there is little debate over the positioning of willingness to sacrifice as a key consumer response outcome variable, viewed either as a manifestation of brand loyalty (e.g., Carroll and Ahuvia, 2006; Jones et al., 2008) or explicitly as an outcome of commitment (Albert and Merunka, 2013; Rusbult et al., 2012).

\section{Cognitive Dimensions:}

Compatibility between Fournier's (1998) and Rusbult's et al., (2001) relationship models is also evident in relation to the derogation (Rusbult et al., 2001) or devaluation (Fournier, 1998) of alternatives. Derogation of alternatives, or the derogation effect, involves the downplaying of the attractiveness of alternative relationship partners and the over- 
estimation, or leniency, in relation to the attractiveness of current relationship partners (Rusbult et al., 2012). Empirically supported in the context of romantic relationships (e.g., Arriaga et al., 2007, and more), the derogation effect may represent an important behavioural outcome of brand relationship commitment. In this sense, the consumer becomes a strong advocate for the brand and, in doing so, is biased toward the strengths of their chosen brand partner, and proactive in highlighting the weaknesses of other brand alternatives (i.e. derogation).

Positive illusions (Rusbult et al., 2012) or biased perceptions (Fournier, 1998) also align with the derogation effect. Positive illusions refer to committed individuals perceiving imperfect relationships in somewhat idealized ways or, in other words, through rose-coloured glasses (Murray and Holmes, 1997). However, positive illusions go beyond simply concentrating on the partner's strengths (while at the same time dismissing their weaknesses) to visualizing strengths that, in reality, do not exist. This is a common occurrence in romantic relationships as partners try to sub-consciously substantiate their relationship and reduce cognitive dissonance (Rusbult et al., 2001). The same could also be said of consumers who engage in brand advocacy behaviour in order to reduce cognitive dissonance (Soutar and Sweeney, 2003; Wangenheim, 2005). Furthermore, understanding positive illusions in relation to brands is important as "positive illusions capture a prospective sense of conviction or security that is not simply isomorphic with satisfaction" (Murray and Holmes 1997, p. 586).

Cognitive interdependence, as discussed by Agnew et al. (1998) in romantic relationships, refers to "a mental state characterized by a pluralistic, collective representation of the self-inrelationship" (p. 939). For example, this is demonstrated by the use of more plural pronouns 
such as "us", "we" and "our". More recently, the common practice of combining partners' names (e.g. Brad Pitt and Angelina Jolie) to label the romantic relationship (e.g. Brangelina) exemplifies the perceived overlap in mental representations of partners involved in highly committed relationships (Agnew et al., 1998). However, this dialectal behaviour is found to be much more specific to romantic relationships, in contrast to relationships involving best friends (Agnew et al., 1998). On this basis, it is less likely that reference to consumer/brand relationships would include such pronouns/labels. However, cognitive interdependence could well manifest itself in the consumer/brand relationship through the use of language characterized by "ownership" (Kachersky and Palermo, 2013; Swaminathan et al., 2007). For example, reference to "my brand" does imply a representation of the self-in-brand relationship and, as such, represents a cognitive manifestation of interdependence (associated with the brand). In addition, it places the brand relationship as central to one's life, a notion advocated by Fournier (1998) and one that is strongly linked to brand intimacy (Long-Tolbert and Gammoh, 2012).

\section{BRAND FIDELITY: DEFINED}

The term "fidelity" has been referred to loosely in the marketing literature, mostly being discussed to as a proxy label for (or closely related to) behavioural loyalty and purchase intentions (e.g., Giannì and Franceschini, 2003; Jones and Taylor, 2007; Ryan et al., 1999) and largely lacking in definition. Of the few researchers, who attempt to define fidelity in the consumer context, there is little agreement over its definition and, subsequent, operationalization. For example, in their study of social contagion in new product adoption, 
Langley et al. (2012) claim fidelity to be the tendency of the consumer "to make accurate copies of new behaviours" (p. 629); the tendency of which is highly dependent on the personality traits of the consumer. In contrast, Dumitrescu and Ichindelean (2011), when studying customer relationship cycles, define customer fidelity as "the felt satisfaction after the consumption of a product/service" (p. 105). Moreover, in multi-format retailing, Arrondo et al. (2002) operationalize fidelity as relative household expenditure level. These disjointed interpretations of fidelity provide little theoretical guidance and highlight the need to justify the use of the term in this current investigation.

We believe, the term "fidelity", appropriately captures of essence of the construct under development here. To clarify, fidelity relates to an individual's faithfulness to a person, cause, or belief, demonstrated by continuing loyalty and support and being faithful implies durability, stability and exclusivity (OED, 2004). Therefore, brand fidelity is a particularly relevant label for our construct as durability, stability and exclusivity are all necessary elements of strong consumer/brand relationships (Fournier, 1998; Fournier and Yao, 1997) and it is the maintenance of such relationships that ground this study. On this basis, we define brand fidelity as the consumer's faithfulness to a brand partner demonstrated by an aggregate of behaviours (i.e. accommodation/forgiveness, willingness to sacrifice) and cognitions (i.e. derogation of alternatives, cognitive interdependence and positive illusions) that maintain relationship stability and durability. Refer Figure 2.

\section{--- Insert Figure 2 Here ---}


In terms of the behavioural manifestations of brand fidelity (i.e. accommodation/forgiveness, willingness to sacrifice) we offer the following definitions:

- Accommodation/forgiveness refers to the degree to which an individual is forgiving of and provides support to a brand partner in times of price/performance variations;

- Willingness to sacrifice refers to the degree to which an individual is willing to make sacrifices to continue their relationship with the brand partner.

Two points of clarification are required here. First, although referred to separately in previous studies of romantic relationships (i.e., Rusbult et al., 2012; Rusbult et al., 2001), for the purpose of understanding consumer/brand relationships, we have collapsed accommodation and forgiveness into one behavioural category based on our previous argument regarding the blurred lines between the two in the context of consumer/brand relations. Second, in adapting our thinking to the current research context, accommodation/forgiveness is referred to, here, in relation to unexpected events associated with price and/or performance variations.

In relation to the cognitive manifestations of brand fidelity, the following definitions are proffered:

- Cognitive interdependence refers to the degree to which an individual feels "at one" with the brand partner and takes personal ownership of the brand

- Derogation of alternatives refers to the degree to which an individual focuses on the strengths of the brand partner and the weaknesses of its competitors; 
- Positive illusions refers to the degree to which an individual has positive illusions of the brand partner, which may (or may not) reflect reality

For clarity, the definitional boundaries and dimensionality of the proposed brand fidelity construct are graphically depicted in Figure 2.

\section{Brand Fidelity in the Bigger Picture}

For the purpose of clarity, Figure 3 provides a pictorial map that essentially summarizes the arguments presented in this paper and the placement of brand fidelity in the "bigger picture". Using Figure 3 as a point of reference, it is important to make some final points of clarification. First, we acknowledge that relationship foundations (i.e. product-related and market-related factors) fundamentally dictate the degree to which consumers wish to establish a relationship with the brand. Higher level brand relationship quality (i.e. commitment, love, fidelity) is not necessarily relevant for all brands as such relationship development and maintenance is highly dependent on product/brand category and marketplace characteristics. In fact, research suggests that the depth of consumer/brand relationships is highly dependent on factors such as product type (i.e. hedonic versus utilitarian) (Chaudhary, 2018), product category involvement (i.e. high versus low involvement (Christy et al., 1996), the brand's personality (Smit et al., 2007) and the type of relational exchange (i.e. B2B versus B2C) (Valta, 2013). Thus, as shown in Figure 3, we acknowledge that such factors establish the boundaries within which the brand fidelity construct has value. 
Second, while brand commitment and brand love take up their rightful position in underpinning the development of consumer/brand relationships, such emotional factors are difficult to articulate and measure (as discussed extensively in this paper). In addition, the strength of the emotional bond the consumer has with the brand is represented by the degree to which they are motivated to work towards maintaining that relationship. Just as with all relationships, a proclamation of love is easy to make; the protection and maintenance of the relationship is a lot more difficult and requires effort from both parties. For these reasons, the brand fidelity construct represents the consumer's behavioural and cognitive "effort" toward relationship maintenance as a true indication of their emotional attachment, over and above that which may be self-reported. In this sense, the strength of the consumer's emotional bond with the brand is inferred by their actions (i.e. brand fidelity).

Finally, we acknowledge that the dimensions of brand fidelity, as shown in Figure 3, hold similarities to other well-researched constructs such as brand citizenship behaviours, attitudinal and behavioural loyalty, switching costs and the like. However, the contribution of brand fidelity to the consumer/brand literature does not reside in its dimensions in isolation, but rather as a formation of these dimensions in representing the gamut of relationship maintenance behaviours/cognitions that are grouped together to form brand fidelity. In other words, the value of the brand fidelity construct is manifested through the synergy of its dimensions. Furthermore, given that individual dimension similarities exist in the literature, the future operationalization of brand fidelity will be well-informed by the literature and, as such, measurement challenges often associated with new scale development will be significantly circumvented. 
--- Insert Figure 3 Here ---

\section{CONCLUSION}

In truly embracing the notion of consumers and brands as "relationship partners", this paper introduces a novel approach to effectively understand consumer cognitions and behaviours that exemplify stable, durable and exclusive consumer/brand relationships. Drawn from the theories associated with commitment and relationship maintenance surrounding romantic love, brand fidelity shows strong promise as a valuable marketing concept and metric worthy of future academic and practitioner attention. Metaphorically, the brand fidelity construct effectively captures the implicit vows that consumers make to their brand partners. For example, when a consumer takes the brand as their own (e.g. cognitive interdependence); they may do so for richer or for poorer (e.g. willingness to sacrifice); in sickness and in health (e.g. accommodation/forgiveness) and forsaking all others (derogation of alternatives). In demonstrating fidelity to their brand partner, consumers explicitly protect and maintain sustainable brand relationships. 


\section{CONFLICT OF INTEREST STATEMENT}

On behalf of all authors, the corresponding author states that there is no conflict of interest.

\section{REFERENCES}

Aaker, D. A. (1996) Building Strong Brands. New York: Free Press.

Agnew, C.R., Van Lange, P.A., Rusbult, C.E. and Langston, C.A. (1998) Cognitive interdependence: Commitment and the mental representation of close relationships. Journal of Personality and Social Psychology 74(4): 939-954.

Alnawas, I. and Altarifi, S. (2016) Exploring the role of brand identification and brand love in generating higher levels of brand loyalty. Journal of Vacation Marketing, 22(2): 111128.

Ahuvia, A., Bagozzi, R.P. and Batra, R. (2014) Psychometric vs. C-OAR-SE measures of brand love: A reply to Rossiter. Marketing Letters 25(2): 235-243.

Ahuvia, A.C. (2005) Beyond the extended self: Loved objects and consumers' identity narratives. Journal of Consumer Research 32(1): 171-184.

Albert, N. and Merunka, D. (2013) The role of brand love in consumer-brand relationships. Journal of Consumer Marketing 30(3): 258-266.

Albert, N., Merunka, D. and Valette-Florence, P. (2008) When consumers love their brands: Exploring the concept and its dimensions. Journal of Business Research 61(10): 10621075.

Amine, A. (1998) Consumers' true brand loyalty: the central role of commitment. Journal of Strategic Marketing 6(4): 305-319. 
Anderson, R.E. (1973) Consumer dissatisfaction: The effect of disconfirmed expectancy on perceived product performance. Journal of Marketing Research 10(1): 38-44.

Arriaga, X.B., Slaughterbeck, E.S., Capezza, N.M. and Hmurovic, J.L. (2007) From bad to worse: Relationship commitment and vulnerability to partner imperfections. Personal Relationships 14(3): 389-409.

Arrondo, E., Berné, C., Múgica, J.M. and Rivera, P. (2002) Modelling of customer retention in multi-format retailing. The International Review of Retail, Distribution and Consumer Research 12(3): 281-296.

Auger, P. and Devinney, T.M. (2007) Do what consumers say matter? The misalignment of preferences with unconstrained ethical intentions. Journal of Business Ethics 76(4): 361-383.

Bagozzi, R. P., Batra, R. and Ahuvia, A. (2017) Brand love: development and validation of a practical scale. Marketing Letters, 28(1): 1-14.

Bansal, H.S., Irving, P.G. and Taylor, S.F. (2004) A three-component model of customer to service providers. Journal of the Academy of Marketing Science 32(3): 234-250.

Batra, R., Ahuvia, A. and Bagozzi, R.P. (2012) Brand love. Journal of Marketing 76(2): 1-16.

Bengtsson, A., Bardhi, F. and Venkatraman, M. (2010) How global brands travel with consumers: An examination of the relationship between brand consistency and meaning across national boundaries. International Marketing Review 27(5): 519-540.

Brucks, M., Zeithaml, V.A. and Naylor, G. (2000) Price and brand name as indicators of quality dimensions for consumer durables. Journal of the Academy of Marketing Science 28(3): 359-374.

Carrington, M.J., Neville, B.A. and Whitwell, G.J. (2010) Why ethical consumers don't walk their talk: Towards a framework for understanding the gap between the ethical 
purchase intentions and actual buying behaviour of ethically minded consumers. Journal of Business Ethics 97(1): 139-158.

Carroll, B.A. and Ahuvia, A.C. (2006) Some antecedents and outcomes of brand love. Marketing Letters 17(2): 79-89.

Chaudhary, A. H. (2018). Brand love: fiction or reality?. Journal of Strategic Marketing, Available: https://doi.org/10.1080/0965254X.2018.1430056

Chaudhuri, A. and Holbrook, M.B. (2002) Product-class effects on brand commitment and brand outcomes: The role of brand trust and brand affect", The Journal of Brand Management 10(1): 33-58.

Christodoulides, G. and De Chernatony, L. (2010) Consumer-based brand equity conceptualization and measurement: A literature review. International Journal of Research in Marketing 52(1): 43-66.

Cifci, S. D. and Erdogan, B. Z. (2016) Antecedents and measurement of brand commitment and behavioural loyalty. Journal of Customer Behaviour, 15(4): 321-336.

Christy, R., Oliver, G. and Penn, J. (1996) Relationship marketing in consumer markets, Journal of Marketing and Management, 12(1): 175-187.

Churchill, G.A., Jr. and Surprenant, C. (1982) An investigation into the determinants of customer satisfaction. Journal of Marketing Research 19(4): 491-504.

Crosby, L.A. and Taylor, J.R. (1983) Psychological commitment and its effects on post-decision evaluation and preference stability among voters. Journal of Consumer Research 9(4): 413-431.

Day, G.S. (1977) Diagnosing the product portfolio. Journal of Marketing, 41(2): 29-38. 
Del Vecchio, D. (2000) Moving beyond fit: the role of brand portfolio characteristics in consumer evaluations of brand reliability. Journal of Product \& Brand Management 9(7): 457-471.

de Oliveira Santini, F., Ladeira, W. J., Sampaio, C. H. and Pinto, D. C. (2018) The brand experience extended model: A meta-analysis. Journal of Brand Management, Available: https://doi.org/10.1057/s41262-018-0104-6

Dick, A.S. and Basu, K. (1994) Customer loyalty: toward an integrated conceptual framework. Journal of the Academy of Marketing Science 22(2): 99-113.

Dowling, G. (2002) Customer relationship management: In B2C markets, often less is more. California Management Review, 44(3): 87-104.

Dumitrescu, L. and Ichindelean, M. (2011) Value Chain and Customer Relationship Cycle: Two Concepts of Relationship Marketing. International Journal of Trade, Economics and Finance 2(2): 103-108.

Eisingerich, A.B. and Rubera, G. (2010) Drivers of brand commitment: A cross-national investigation. Journal of International Marketing, 18(2): 64-79.

Fehr, B. and Russell, J.A. (1991) The concept of love viewed from a prototype perspective. Journal of Personality and Social Psychology 60(3): 425-438.

Fetscherin, M., Boulanger, M., Gonçalves Filho, C. and Quiroga Souki, G. (2014) The effect of product category on consumer brand relationships. Journal of Product \& Brand Management 23(2): 78-89.

Finkel, E.J., Rusbult, C.E., Kumashiro, M. and Hannon, P.A. (2002) Dealing with betrayal in close relationships: does commitment promote forgiveness? Journal of Personality and Social Psychology 82(6): 956-974. 
Fournier, S. (1998) Consumers and their brands: Developing relationship theory in consumer research. Journal of Consumer Research 24(4): 343-353.

Fournier, S. and Yao, J.L. (1997) Reviving brand loyalty: A reconceptualization within the framework of consumer-brand relationships. International Journal of Research in Marketing 14(5): 451-472.

Garg, R. Mukherjee, J., Biswas, S and Kataria, A. (2016) An investigation into the concept of brand love and its proximal and distal covariates. Journal of Relationship Marketing, 15(3):135-153

Gianni, G. and Franceschini, F. (2003) A new model to support the personalised management of a quality e-commerce service. International Journal of Service Industry Management 14(3): 331-346.

Giovanis, A. (2016) Consumer-brand relationships' development in the mobile internet market: evidence from an extended relationship commitment paradigm. Journal of Product \& Brand Management, 25(6): 568-585.

Green, A., Grace, D. and Perkins, H. (2016) City branding research and practice: An integrative review. Journal of Brand Management, 23(3): 252-272.

Hatfield, E., Traupmann, J. and Sprecher, S. (1984) Older women's perceptions of their intimate relationships. Journal of Social and Clinical Psychology, 2(2): 108-124.

Hegner, S. M., Fenko, A. and Teravest, A. (2017) Using the theory of planned behaviour to understand brand love. Journal of Product \& Brand Management, 26(1): 26-41.

Hennig-Thurau, T. and Klee, A. (1997) The impact of customer satisfaction and relationship quality on customer retention: A critical reassessment and model development. Psychology \& Marketing 14(8): 737-764. 
Hirschman, A.O. (1970) Exit, Voice, and Loyalty: Responses to Decline in Firms, Organisations, and States. Harvard University Press: Cambridge, MA.

Hirschman, E.C. and Holbrook, M.B. (1992) Postmodern Consumer Research: The Study of Consumption as Text. Sage Publications: Newbury Park, CA.

Huang, L.-T., Cheng, T.-C. and Farn, C.-K. (2007) The mediating effect of commitment on customer loyalty towards e-brokerages: an enhanced investment model. Total Quality Management \& Business Excellence 18(7): 751-770.

Jacoby, J. and Chestnut, R.W. (1978) Brand loyalty: Measurement and management. Ronald Press: New York.

Jacoby, J. and Kyner, D.B. (1973) Brand loyalty vs. repeat purchasing behaviour. Journal of Marketing Research 10(1): 1-9.

Jones, T., Fox, G.L., Taylor, S.F. and Fabrigar, L.R. (2010) Service customer commitment and response. Journal of Services Marketing 24(1): 16-28.

Jones, T. and Taylor, S.F. (2007) The conceptual domain of service loyalty: how many dimensions? Journal of Services Marketing 21(1): 36-51.

Jones, T., Taylor, S.F. and Bansal, H.S. (2008) Commitment to a friend, a service provider, or a service company-are they distinctions worth making? Journal of the Academy of Marketing Science 36(4): 473-487.

Kachersky, L. and Palermo, N. (2013) How personal pronouns influence brand name preference, The Journal of Brand Management 20(7): 558-570.

Keller, K.L. (1993) Conceptualizing, measuring, and managing customer-based brand equity. Journal of Marketing 57(1): 1-22.

Keller, K.L. (2001). Building Customer-Based Brand Equity: A Blueprint for Creating Strong Brands. Cambridge, MA: Marketing Science Institute (MSI). 
Keller, K. L. (2009) Building strong brands in a modern marketing communications environment. Journal of Marketing Communications, 15(2-3): 139-155.

Kim, J., Morris, J.D. and Swait, J. (2008) Antecedents of true brand loyalty. Journal of Advertising 37(2): 99-117.

Langley, D.J., Bijmolt, T.H., Ortt, J.R. and Pals, N. (2012) Determinants of social contagion during new product adoption. Journal of Product Innovation Management 29(4): 623638.

Langner, T., Bruns, D., Fischer, A. and Rossiter, J.R. (2014) Falling in love with brands: a dynamic analysis of the trajectories of brand love. Marketing Letters 27(1): 1-12.

Leckie, C., Nyadzayo, M. W. and Johnson, L. W. (2016) Antecedents of consumer brand engagement and brand loyalty. Journal of Marketing Management, 32(5-6): 558-578.

Li, X.R. and Petrick, J.F. (2008) Examining the antecedents of brand loyalty from an investment model perspective. Journal of Travel Research 47(1): 25-34.

Long-Tolbert, S.J. and Gammoh, B.S. (2012) In good and bad times: The interpersonal nature of brand love in service relationships Journal of Services Marketing 26(6): 391-402.

Loureiro, S.M.C., Ruediger, K.H. and Demetris, V. (2012) Brand emotional connection and loyalty. Journal of Brand Management 20(1): 13-27.

Mattila, A.S. (2001) The impact of relationship type on customer loyalty in a context of service failures. Journal of Service Research 4(2): 91-101.

Mattila, A.S. (2006) How affective commitment boosts guest loyalty (and promotes frequentguest programs). Cornell Hotel and Restaurant Administration Quarterly 47(2): 174181. 
Maxian, W., Bradley, S.D., Wise, W. and Toulouse, E.N. (2013) Brand love is in the heart: Physiological responding to advertised brands. Psychology \& Marketing 30(6): 469478.

McAlister, L. (1982) A dynamic attribute satiation model of variety-seeking behaviour. Journal of Consumer Research 9(2): 141-150.

Miller, J.A. (1977) Studying satisfaction, modifying models, eliciting expectations, posing problems, and making meaningful measurements. in Hunt, H.K. (ed), Conceptualization and measurement of consumer satisfaction and dissatisfaction. Marketing Science Institute, Cambridge, MA: 72-91.

Mitra, A. and Lynch, J.G., Jr. (1995) Toward a reconciliation of market power and information theories of advertising effects on price elasticity. Journal of Consumer Research 21(4): 644-659.

Moorman, C., Zaltman, G. and Deshpande, R. (1992) Relationships between providers and users of market research: The dynamics of trust within and between organizations. Journal of Marketing Research 29(3): 314-328.

Morgan, R.M. and Hunt, S.D. (1994) The commitment-trust theory of relationship marketing. Journal of Marketing 58(3): 20-38.

Murray, S.L. and Holmes, J.G. (1997) A leap of faith? Positive illusions in romantic relationships. Personality and Social Psychology Bulletin 23(6): 586-604.

Nam, J., Ekinci, Y. and Whyatt, G. (2011) Brand equity, brand loyalty and consumer satisfaction. Annals of Tourism Research 38(3): 1009-1030.

Nusair, K., Hua, N. and Li, X. (2010) A conceptual framework of relationship commitment: etravel agencies. Journal of Hospitality and Tourism Technology 1(2): 106-120. 
OED. (2004) Oxford English Dictionary. available at: http://dictionary.oed.com (20 March 2014).

Oliver, R.L. (1977) A theoretical reinterpretation of expectation and disconfirmation effects on posterior product evaluation: Experiences in the field. in Day, R. (ed), Consumer Satisfaction, Dissatisfaction and Complaining Behaviour. Indiana University, Bloomington: 2-9.

Oliver, R.L. (1999) Whence consumer loyalty? Journal of Marketing, 63: 33-44.

Olshavsky, R.W. and Miller, J.A. (1972) Consumer expectations, product performance, and perceived product quality. Journal of Marketing Research 9(1): 19-21.

Olson, J.C. and Dover, P. (1976) Effects of expectation creation and disconfirmation on belief elements of cognitive structure. in Anderson, B.B. (ed), Advances in Consumer Research. Association for Consumer Research, Chicago: 168-175.

Park, C.W., Jaworski, B.J. and MacInnis, D.J. (1986) Strategic brand concept-image management. Journal of Marketing 50(4): 135-145.

Park, J.-W., Kim, K.-H. and Kim, J.K. (2002) Acceptance of brand extensions: Interactive influences of product category similarity, typicality of claimed benefits, and brand relationship quality. in Broniarczyk, S. and Nakamoto, K. (eds), Advances in Consumer Research. Association for Consumer Research, Valdosta, GA: 190-198.

Patton, M.Q. (2002) Qualitative Research and Evaluation Methods. Thousand Oaks, CA: Sage.

Pfaff, A.B. (1972) An index of consumer satisfaction. in Venkatesan, M. (ed), Proceedings of the Third Annual Conference of the Association for Consumer Research, Association for Consumer Research, Chicago: 713-737. 
Popp, B. and Woratschek, H. (2017) Consumer-brand identification revisited: An integrative framework of brand identification, customer satisfaction, and price image and their role for brand loyalty and word of mouth. Journal of Brand Management, 24(3): 250270.

Pulligadda, S., Kardes, F. R. and Cronley, M. L. (2016) Positive affectivity as a predictor of consumers' propensity to be brand loyal. Journal of Brand Management, 23(2): 216228.

Punniyamoorthy, M. and Raj, M.P.M. (2007) An empirical model for brand loyalty measurement. Journal of Targeting, Measurement and Analysis for Marketing 15(4): 222-233.

Rauschnabel, P.A. and Ahuvia, A.C. (2014) You're so lovable: Anthropomorphism and brand love. Journal of Brand Management 21(5): 372-395.

Reichheld, F.F. and Teal, T. (1996) The Loyalty Effect: The Hidden Force Behind Growth, Profits, and Lasting Value. Harvard Business School: Boston, MA.

Reynolds, K.E. and Beatty, S.E. (1999) Customer benefits and company consequences of customer-salesperson relationships in retailing. Journal of Retailing 75(1): 11-32.

Reynolds, T.J. and Gutman, J. (1984) Advertising is image management. Journal of Advertising Research 24(1): 27-37.

Rossiter, J.R. (2012) A new C-OAR-SE-based content-valid and predictively valid measure that distinguishes brand love from brand liking. Marketing Letters 23(3): 905-916.

Roy, S.K., Eshghi, A. and Sarkar, A. (2013) Antecedents and consequences of brand love. Journal of Brand Management 20 (4): 325-332.

Rusbult, C.E. (1980) Commitment and satisfaction in romantic associations: A test of the investment model. Journal of Experimental Social Psychology 16 (2): 172-186. 
Rusbult, C.E., Agnew, C.R. and Arriaga, X.B. (2012) The investment model of commitment processes. in Van Lange, P.A.M., Kruglanski, A.W. and Higgins, E.T. (eds), Handbook of Theories of Social Psychology. Sage: Thousand Oaks: CA: 218-231.

Rusbult, C.E. and Buunk, B.P. (1993) Commitment processes in close relationships: An interdependence analysis. Journal of Social and Personal Relationships 10(2): 175-204.

Rusbult, C.E., Martz, J.M. and Agnew, C.R. (1998) The investment model scale: Measuring commitment level, satisfaction level, quality of alternatives, and investment size. Personal Relationships 5(4): 357-387.

Rusbult, C.E., Olsen, N., Davis, J.L. and Hannon, P.A. (2001) Commitment and relationship maintenance mechanisms. in Harvey, J. and Wenzel, A. (eds), Close Romantic Relationships: Maintenance and Enhancement. Erlbaum: Mahwah NJ: 87-113.

Rusbult, C.E., Verette, J., Whitney, G.A., Slovik, L.F. and Lipkus, I. (1991) Accommodation processes in close relationships: Theory and preliminary empirical evidence. Journal of Personality and Social Psychology 60(4): 53-78.

Rusbult, C.E., Zembrodt, I.M. and Gunn, L.K. (1982) Exit, voice, loyalty, and neglect: Responses to dissatisfaction in romantic involvements. Journal of Personality and Social Psychology 43(6): 1230-1242.

Russell-Bennett, R., McColl-Kennedy, J.R. and Coote, L.V. (2007) Involvement, satisfaction, and brand loyalty in a small business services setting. Journal of Business Research 60(12): 1253-1260.

Ryan, M.J., Rayner, R. and Morrison, A. (1999) Diagnosing customer loyalty drivers. Marketing Research 11(2): 19-26.

Sarkar, A., Ponnam, A. and Murthy, B.K. (2012) Understanding and measuring romantic brand love. Journal of Customer Behaviour 11(4): 324-347. 
Sheth, J.N. and Parvatiyar, A. (1995) Relationship marketing in consumer markets:

Antecendents and consequences. Journal of the Academy of Marketing Science 23(4): 255-271.

Shimp, T.A. and Madden, T.J. (1988) Consumer-object relations: A conceptual framework based analogously on Sternberg's Triangular Theory of Love. in Houston, M. (ed), Advances in Consumer Research. Association for Consumer Research: Provo, UT: 163168.

Sirgy, M.J. (1982) Self-concept in consumer behaviour: A critical review. Journal of Consumer Research 9(3): pp. 287-300.

Smit, E., Bronner, F. and Tolboom, M. (2007) Brand relationship quality and its value for personal contact. Journal of Business Research, 60(6): 627-633.

Solomon, M.R. (1983) The role of products as social stimuli: A symbolic interactionism perspective. Journal of Consumer Research 10(3): 319-329.

Soutar, G.N. and Sweeney, J.C. (2003) Are there cognitive dissonance segments? Australian Journal of Management 28(3): 227-249.

Sternberg, R.J. (1986) A triangular theory of love. Psychological Review 93(2): 119.

Swaminathan, V., Page, K.L. and Gürhan-Canli, Z. (2007) "My" brand or "our" brand: The effects of brand relationship dimensions and self-construal on brand evaluations. Journal of Consumer Research 34(2): 248-259.

Thomson, M., Maclnnis, D.J. and Park, C.W. (2005) The ties that bind: Measuring the strength of consumers' emotional attachments to brands. Journal of Consumer Psychology 15(1): 77-91.

Valta, K. S. (2013).Do relational norms matter in consumer-brand relationships? Journal of Business Research, 66(1): 98-104. 
Wallace, E., Buil, I. and de Chernatony, L. (2014) Consumer engagement with self-expressive brands: brand love and WOM outcomes. Journal of Product \& Brand Management 23(1): 33-42.

Wang, J. and Wallendorf, M. (2004) The influence of materialism on product satisfaction. Advances in Consumer Research 31(1): 232-272.

Wangenheim, F.V. (2005) Postswitching negative word of mouth. Journal of Service Research 8(1): 67-78.

White, L. and Yanamandram, V. (2007) A model of customer retention of dissatisfied business services customers. Managing Service Quality: An International Journal 17(3):298316.

Xie, Y. and Peng, S. (2009) How to repair customer trust after negative publicity: The roles of competence, integrity, benevolence, and forgiveness. Psychology \& Marketing 26(7): 572-589.

Zarantonello, L., Formisano, M. and Grappi, S. (2016) The relationship between brand love and actual brand performance: Evidence from an international study. International Marketing Review, 33(6): 806-824. 
Figure 2: Brand Fidelity Defined

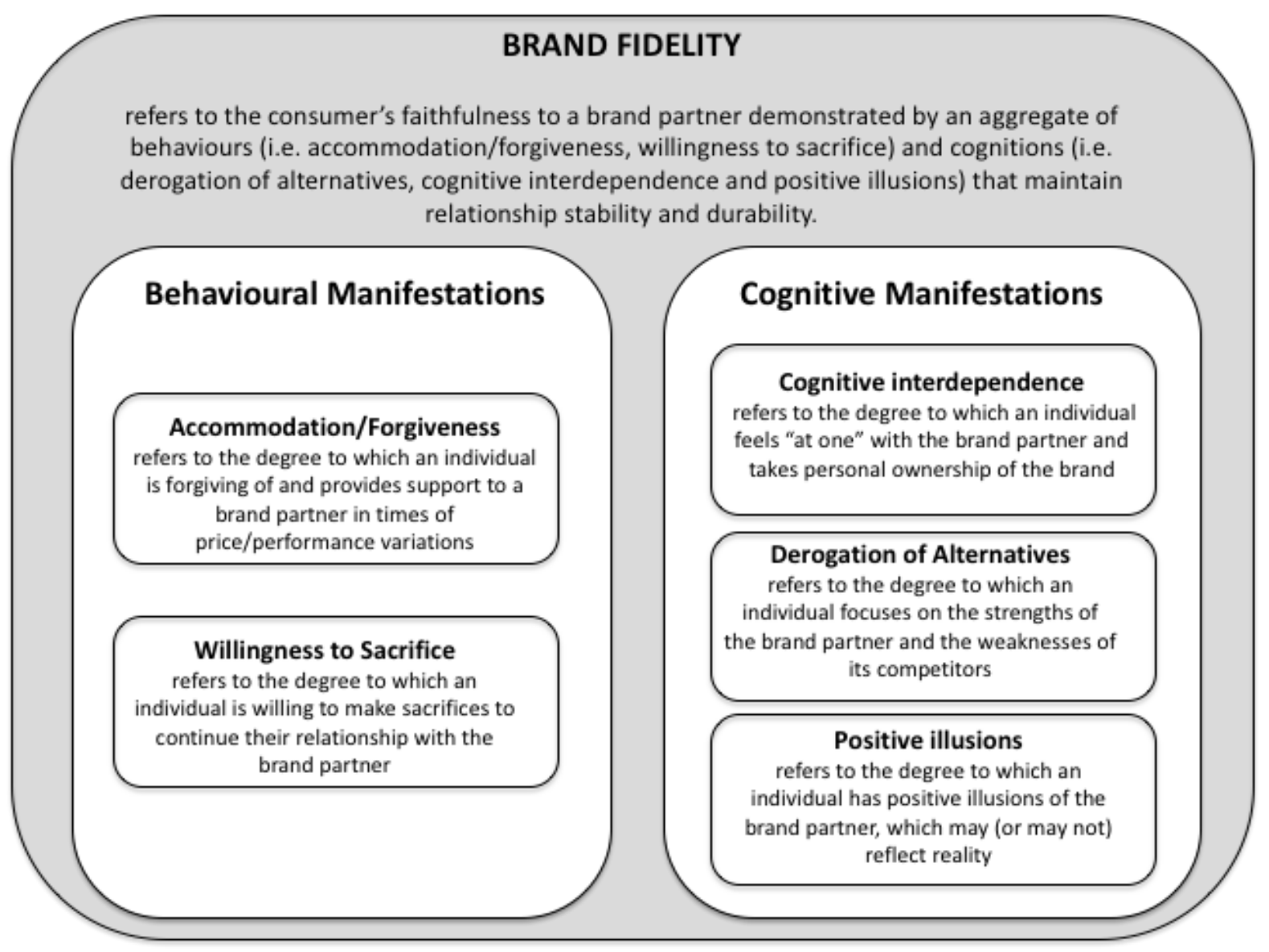


Figure 3: Mapping Consumer/Brand Relationships

Relationship Foundations

Product-Related

- Product Price/Performance (Satisfaction)

- Product Category Involvement

\section{Market-Related}

- Exchange Type

- (B2B vs B2C)

- Accessibility: Investment Factors

\section{Relationship Development}

\section{Relationship Maintenance}

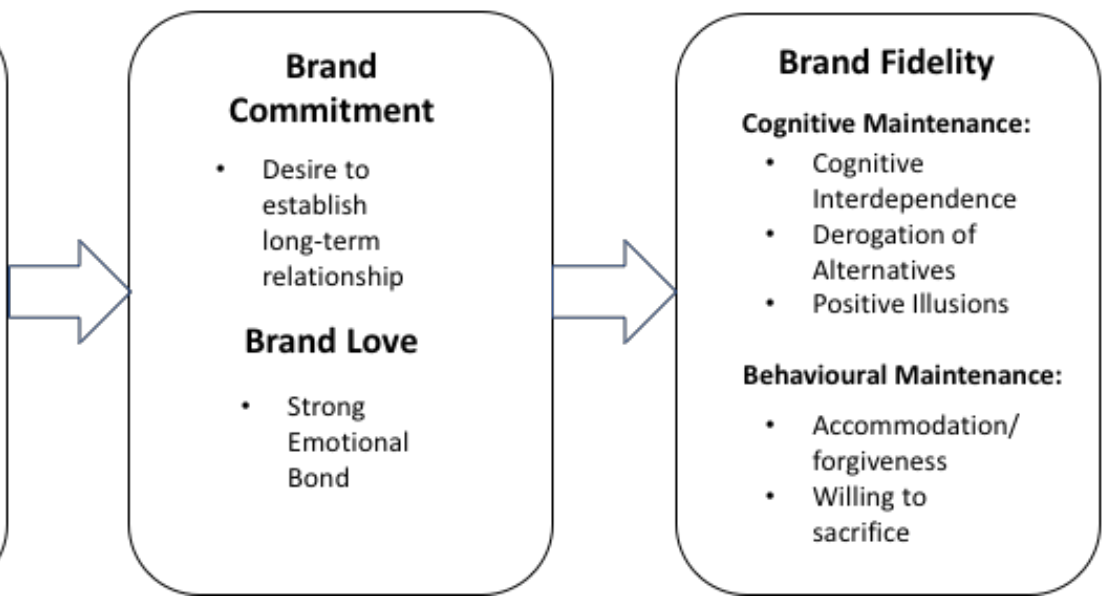

